\title{
Party Unity in Parliamentary Democracies: A Comparative Analysis
}

\author{
ULRICH SIEBERER
}

The level and causes of party unity are under researched topics in parliamentary democracies, particularly in comparative perspective. This article presents a non formal model explaining party unity in legislative voting as the result of individual legislators' decisions reacting to the incentives and constraints created by their respective institutional environments. Hypotheses derived from the model are tested against empirical data on party unity in 11 western parliamentary democracies since 1945. On the system level, central party control over nominations and intra parliamentary resources as well as the strength of parliamentary committees with regard to policy decisions are shown to affect party unity as expected by the model. On the level of individual parties, governing parties are less unified than opposition parties and larger parties show higher unity than smaller ones. Both results shed doubt on frequent claims in the literature.

Parliamentary voting is the fundamental mechanism for making collectively binding decisions in modern democracies. Formally, these decisions are made by individual deputies with a free mandate only accountable to their voters, though the reality in parliamentary democracies looks different: usually, the members of parliamentary party groups (PPGs) vote together PPGs are the relevant actors in parliamentary business. ${ }^{1}$ Parts of the literature have reacted to this by treating PPGs as unitary actors, with regard to both policy decisions and coalition formation. ${ }^{2}$ Party specialists, on the other hand, emphasise the heterogeneity of political parties. ${ }^{3}$ Given the diversity of interests within parties, party unity in legislative voting cannot simply be assumed, but needs to be explained. What makes individual deputies vote in line with their parliamentary parties? Even though this question has recently received increased attention, ${ }^{4}$ there are still only very few comparative studies on this building block of the theory of parliaments.

Ulrich Sieberer is a Lecturer in the Department of Social Sciences at the University of Mannheim.

This article developed out of a Master's Thesis at the University of Mannheim. The author is grateful to Peter Graf Kielmansegg and Franz Urban Pappi for their advice and supervision of the thesis. Thanks go to André Kaiser, Bernhard Miller, Wolfgang C. Müller and three anonymous referees for valuable comments and suggestions. Thanks are also due to John Carey, Philip Cowley and Asbjorn Skjaeveland, who shared unpublished data or offered advice on calculating Rice scores. 
This article attempts to take one step in this direction by analysing party unity in 11 established parliamentary democracies. First, it presents a theoretically consistent model that explains party unity as the result of individual decisions taken by rational deputies reacting to the institutional incentives and constraints in their respective countries. ${ }^{5}$ From this model, hypotheses are derived that are tested against available data both at the system level and at the level of individual parties. The results support many of the institutional hypotheses, but shed doubt on recent claims in the literature expecting governing parties to be more unified than opposition parties. The implications of these findings for legislative studies more generally are discussed before concluding.

\section{PARTY UNITY: A PHENOMENON IN NEED OF EXPLANATION}

It is useful to start by clarifying some terminological issues. The terms 'unity', 'cohesion' and 'discipline' are often used interchangeably. None the less, it is useful to keep them apart as referring to different analytical concepts, despite the difficulties of isolating the concepts in empirical research. In line with recent work, 'unity' is here used for the observable degree to which members of a group act in unison. Unity can be brought about via two analytically distinct paths. First, it can be caused by shared preferences; this is referred to as 'cohesion'. Second, unity can result from sanctions or positive incentives that make members vote together even though their preferences differ; this is referred to as 'discipline'.

Ozbudun has produced the first broad comparative analysis of party unity. ${ }^{7}$ Despite its path-breaking character, his study suffers from two weaknesses. First, it employs a very heterogeneous array of explanatory concepts lacking theoretical consistency. Second, Ozbudun does not systematically test his hypotheses, mainly due to the lack of data on legislative voting behaviour suitable for statistical analysis. There are some more recent comparative studies using roll-call data that focus mainly on differences between parliamentary and presidential systems. ${ }^{8}$ A few other studies explain party unity in a very small sample of parliamentary systems. ${ }^{9}$ In addition, there have been several attempts to explain party unity in individual parliamentary systems. ${ }^{10}$ An early focus was on the UK, particularly during the turbulent 1970s. ${ }^{11}$ Recent country studies based on roll-call data are also available for Germany, Norway, Denmark, Belgium and, most recently, Italy. ${ }^{12}$

A broad comparative study of party unity in parliamentary democracies based on roll-call data is still lacking. There are a number of reasons for limiting such a study to parliamentary democracies, that is, to countries in which the government can be forced to resign by a majority vote in parliament. On the theoretical level, a parliamentary system of government by itself 
offers strong incentives for party unity as a precondition of a cabinet's survival and effectiveness. Empirically, it is observed that party unity is much higher and more stable in parliamentary systems than in presidential systems. This is particularly true when established western European and Anglo-Saxon countries are analysed. A comparative study including both parliamentary and presidential systems would ascribe most of the variance to the regime type and would leave unexplained smaller but none the less interesting differences within the group of parliamentary systems.

\section{AN EXPLANATORY MODEL}

In order to explain different levels of party unity in parliamentary systems, I propose a non-formal model based on the rationalist variant of the "new institutionalism'. The actors in this model are mainly members of parliament (MPs) who are divided into two groups the PPG leadership and the backbenchers. When extra-parliamentary party leaders or government ministers are relevant they are treated as part of the PPG leadership, in line with the model of the British front bench. Actors are assumed to be motivated primarily by the desire to be re-elected. Personal rise in power and influencing policy are seen as secondary motivations whose realisation is tied to the necessary condition of being re-elected. ${ }^{13}$

Members of the PPG leadership who usually do not have to worry about re-election because they are placed high on party lists or run in safe districts are, furthermore, assumed to care about the unity of their PPG. They internalise the interests of the PPG as a collective group. ${ }^{14}$ Ensuring PPG unity helps the leadership achieve its secondary motivations. First, the PPG leadership can exercise disproportionate influence on the policy position of the PPG, thus furthering its own policy interests. Second, successful management of the PPG helps secure leadership positions with the privileges tied to these positions and may promote personal advancement to other attractive jobs, such as cabinet offices.

For backbenchers, on the other hand, re-election is a more pressing concern. In addition, they strive for personal advancement within the hierarchy of the PPG and parliament. The degree to which backbenchers have incentives to pursue these goals by toeing the party line or by taking independent positions depends on the institutional determinants of re-election and potential paths of promotion. If individual MPs can reach their goals only through the party leadership, they are likely to toe the party line. ${ }^{15}$ If alternative paths open up through a direct relationship with voters or through alternative arenas of influence, such as parliamentary committees, deputies can be faced with contradictory demands, which call into question their loyalty towards their PPG and can thus lead to lower party unity. It is 
important to emphasise that unity is not necessarily lower in this case. Depending on the preference ordering and the weight given to contradictory demands, deputies can also decide to remain loyal to the demands of their PPG.

The model includes three groups of independent variables, the first of which is temporarily prior to the other two (Figure 1). The variables in the first group deal with the way deputies gain their seats, whereas the variables in the other two groups relate to the dependency of deputies on their PPGs in parliament. Here I distinguish between structural dependencies, which apply to all MPs in a given parliament, and situational resources, which vary between parties. The variables in the first two groups are constant for all parties acting in a particular system and thus seek explanation of party unity at the level of the political system. ${ }^{16}$ The variables in the third group vary within systems and help explain differences at the level of individual parties.

The model conceptualises party unity as the result of individual decisions by deputies who are influenced by institutional incentives and constraints. The different groups of variables indicate that one particular level of unity can be reached by several, at least theoretically, distinguishable paths. None the less, there are relations between these groups of variables. First, who gains parliamentary seats due to the variables in the first group obviously influences how parliament operates later on. Second, structural variables in the second group offer more or less room for the consequences that situational variables in the third group may have. These background conditions are indicated by dashed arrows in Figure 1. Feedback effects between the different groups of variables are not included in the model. ${ }^{17}$

FIGURE 1

AN EXPLANATORY MODEL FOR PARTY UNITY IN PARLIAMENTARY DEMOCRACIES
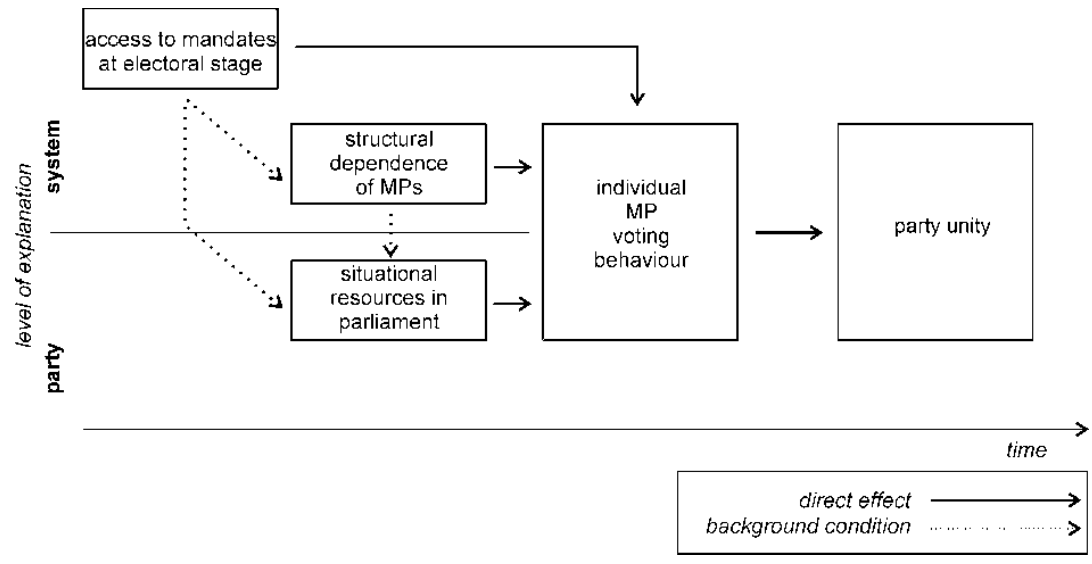
From this model, a number of empirically testable hypotheses can be derived. All of those have already been discussed in the literature, either in comparative or in single-country studies. ${ }^{18}$ What is novel about this presentation is that all these hypotheses are integrated into a consistent theoretical framework and will be tested using comparative empirical data.

\section{The Electoral Stage}

The first group of variables deals with how deputies get their mandates. In western democracies, parliamentarians are popularly elected. In this process, parties play a crucial role. Parties nominate candidates, they offer programmes based on which voters can make an informed choice, they finance and organise electoral campaigns in short the electoral process in parliamentary democracies is nowadays unthinkable without political parties. Accordingly, MPs are primarily conceptualised as agents of their respective parties. ${ }^{19}$

The goal of the party leadership, both within parliament and in the extraparliamentary party organisation, consists of selecting a group of MPs that can be expected to be cohesive and thus display unity without the need for disciplinary measures. At the same time, the leadership cannot completely streamline the array of candidates for electoral and informational reasons. Especially large parties representing more than one social group have incentives to diversify their offer, thus accepting a certain degree of preference heterogeneity among candidates. In addition, candidates from different backgrounds can contribute valuable informational resources and skills to the PPG. None the less, the leadership is likely to try to sort out known rebels from different intra-party groups.

The question is thus to what degree the party leadership is able to handpick candidates for parliament who can be expected to vote in line with the leadership's wishes. Institutionally, the freedom of the leadership to select candidates depends on the electoral system, understood in a broad sense to include the process of candidate selection. Relevant variables are the central control over party nomination and the incentives offered by the electoral system to pursue personal vote strategies.

Control of nominations refers to the ways in which candidates gain access to the party label and its privileges in campaigning and the electoral process. The more the nomination procedures are under the control of the party leadership, the more this group can determine the future composition of the PPG according to its wishes. If, on the other hand, citizens are actively involved in candidate selection, as in the case of primaries or strong preference voting, such opportunities for centralised control disappear. Between these extremes a variety of rules exist, both with regard to the selecting body and the level at which candidates are selected. ${ }^{20}$ The influence of the central party leadership is strongest when it can nominate candidates directly, 
weaker when it can only veto decisions made at a lower (regional or local) level and weakest when party members are involved directly in the selection process. ${ }^{21}$ This leads to

Hypothesis 1.1: The more control over candidate selection for parliamentary elections is concentrated in the hands of the central party leadership, the higher is the unity of a PPG.

Even though we can expect parties to be the most important basis for voters' decisions in established parliamentary systems, the electoral system can encourage MPs to build up a personal vote through closer ties with their voters. ${ }^{22}$ The literature offers several attempts to classify electoral systems depending on the incentives they offer for personal vote strategies. ${ }^{23}$ The stronger these incentives are, the more independent MPs become from their parties with respect to their election and re-election. In addition, closer ties with constituents are likely to produce more direct policy demands from the constituency, which may be at odds with the party line. ${ }^{24}$ Both points lead to

Hypothesis 1.2: The stronger the incentives to cultivate a personal vote offered by the electoral system, the lower is the unity of a PPG.

\section{Structural Dependence within Parliament}

The variables in the second group deal with the degree to which deputies are dependent on their PPGs (that is, in practice, the PPG leadership) in everyday parliamentary business. This dependence is crucial for the questions of how backbenchers pursue their secondary motives of personal advancement and policy influence and how they acquire the information necessary for making informed decisions.

The party leadership pursues two partly conflicting goals. On the one hand, it tries to control the behaviour of its PPG members in order to guarantee party unity. On the other hand, the complexity of modern politics requires delegating tasks to backbenchers. This delegation involves the transfer of resources that can also be used against the PPG leadership. Alternative arenas for information gathering and policy influence, especially strong committees, are thus dangerous for the party leadership as they call into question the PPG's monopoly on information and policy co-ordination.

This article analyses four areas of parliamentary organisation that affect the ability of the party leadership to control backbenchers in parliament: (1) the central control of procedural, financial and organisational resources; (2) the potential for patronage; (3) available sanctions; and (4) the structure of the committee system.

If the control over financial and staff resources is centralised in the hands of the PPG leadership, this group is able largely to monopolise expertise and 
information. ${ }^{25}$ Deputies are then hardly able to work out alternative proposals and to dissent in an informed fashion. In addition, the PPG leadership often enjoys procedural privileges with regard to parliamentary business, such as control of the parliamentary agenda (often together with the government) and the right to initiate bills and amendments. Thus:

Hypothesis 2.1: The more control of intra-parliamentary resources is centralised in the hands of the PPG leadership, the higher is PPG unity.

The PPG leadership can entice party unity via patronage if it is able to deliver attractive positions, such as leadership posts in the PPG, in the parliamentary hierarchy, in parliamentary committees and (probably most valued) in the cabinet. Conversely, strong rules of seniority and frequent access of nonparliamentarians to important offices should weaken these positive incentives and should thus lead to lower unity. Therefore:

Hypothesis 2.2: The more the personal advancement of MPs in the PPG, in parliament and into the government is controlled by the PPG leadership, the higher is PPG unity.

The PPG leadership can also use negative incentives such as recall from committees, non-considerations for higher offices (the direct opposite of the positive incentives mentioned above) and, finally, expulsion from the PPG. ${ }^{26}$ These sanctions do not necessarily have to be used frequently in order to have an effect; the threat of their use only has to be credible. ${ }^{27}$ Thus:

\section{Hypothesis 2.3: The higher the potential sanctions the PPG leadership can employ towards dissenters and the more credible the use of these sanctions, the higher is PPG unity.}

Finally, deputies are less dependent on their PPGs if alternative parliamentary arenas exist for gaining information and exercising policy influence. Parliamentary committees offer such potential alternatives to the PPG both for influencing policy decisions and for gaining independent information and expertise. ${ }^{28}$ In committees, deputies are able to inform themselves about issues at stake and exert some influence over policy decisions in a forum that may be less controlled by the party leadership than the plenary. In addition, committees may offer alternative career paths for deputies less strictly controlled by the PPG leaderships, especially if seniority rules apply. Strong committees may thus offer arenas for deputies to pursue their policy and career goals somewhat more independently of their respective party leaderships. ${ }^{29}$ This enhanced independence may be visible in more independent voting behaviour and may thus reduce observed PPG unity. Therefore: 
Hypothesis 2.4: The stronger parliamentary committees are, the lower is $P P G$ unity.

\section{The Situational Allocation of Resources in Parliament}

The structural dependence of deputies on their PPGs and their voters analysed so far refers to the political system as a whole and is relatively stable over time. The variables in the third group vary both over time and between parties because they follow directly from the most recent elections and subsequent decisions by the relevant political actors. The structurally defined position of the PPG leadership vis-à-vis backbenchers can be strengthened or weakened because of the situational distribution of resources, which thus influences the incentives for party unity. For this group of variables, the level of analysis shifts from the system level to the level of individual PPGs because situational factors affect them differently. The variables analysed here are: (1) government participation of a PPG; (2) its size; (3) the margin of the government; and (4) the position of a PPG in policy space.

First, the unity of a PPG should differ between government and opposition parties. Much of the recent literature expects government parties to be more unified. Reasons mentioned include the larger potential for patronage, the vote of confidence as a disciplining device and the increased importance of unity as a prerequisite for effective governing. ${ }^{30}$ All these (positive and negative) incentives for unity are relevant only for members of governing parties; they do not apply to opposition parties. On the other hand, we might also expect government membership to decrease unity because governing parties cannot avoid taking a position on divisive issues and are often forced to accept compromises, especially in coalition governments. These factors might lead to more defection by unsatisfied members. ${ }^{31}$ Thus there are two rival hypotheses to be considered:

Hypothesis 3.1a: Government parties are more unified than opposition parties.

Hypothesis 3.1b: Government parties are less unified than opposition parties.

Second, I expect the size of a PPG to influence its unity. A larger party is probably more heterogeneous with regard to the preferences of its members so that cohesion based on agreement is less likely. In addition, the costs of monitoring increase with the size of the group. This leads to another hypothesis frequently found in the literature: ${ }^{32}$

Hypothesis 3.2: The larger a PPG is, the lower is its unity.

A third relevant factor is the margin the government parties enjoy vis-à-vis the opposition. ${ }^{33}$ If the margin is large, the government can afford some disunity 
without endangering winning the vote. Under such circumstances, the PPG leadership should be more willing to tolerate some defections, whereas it will insist on complete unity when its margin over the opposition is close and thus every vote is needed. ${ }^{34}$ This connection is less clear for opposition parties, for whom the threat of losing the vote does not provide an incentive for unity. On the other hand, opposition parties may strive for high unity in the hope of winning an occasional vote due to disunity within the governing parties. In addition, a unified appearance may be important for presenting itself as a serious alternative to the voters. Both arguments speak for a positive relationship between closeness of margin and unity for opposition parties as well. Therefore:

\section{Hypothesis 3.3: The closer the margin of the governing parties over the opposition, the higher is PPG unity.}

Fourth, I expect a connection between party unity and the spatial location of a PPG. ${ }^{35}$ The closer a PPG is to other parties in policy terms, the more likely it is that an MP dissatisfied with his/her party's position will find alternatives more in line with his/her preferences in neighbouring PPGs. In addition, such PPGs stand by as alternatives if the MP were to be expelled from his/her party, so that the cost of switching parties decreases. Such alternatives are not available to members of isolated PPGs. Thus:

Hypothesis 3.4: The more isolated a PPG is in policy space, the higher is its unity.

\section{DATA AND CASES}

For an empirical testing of these hypotheses, the first question is how to measure party unity, the dependent variable in the model. Throughout this article, party unity is understood as unity in parliamentary voting. Party unity can be conceptualised more broadly and can be analysed in various other contexts besides parliamentary voting. ${ }^{36}$ I focus on voting unity because this constitutes the ultimate test for the ability of a parliamentary party to act in unison. Of course this decision forces me to reduce rich and important processes of bargaining into a binary choice, but this is also the choice faced by political actors when it comes to voting. Nothing in this argument denies the importance of arguing, bargaining and compromising prior to the vote.

The most common measure of party unity in legislative voting is the Rice Index of Cohesion. ${ }^{37}$ The index captures both the frequency of dissenting behaviour and the size of the dissenting group. It is calculated as the absolute value of the difference between yes and no votes in a PPG on any specific vote. $^{38}$ These values are then aggregated, usually either over a full 
inter-election period or over a yearly session. The index ranges from zero when half of the PPG vote yes and no respectively, to 100 when all members vote either yes or no. Abstentions and non-voting are ignored in the original version of the score. ${ }^{39}$

The Rice Index is the standard measure in the literature and will also be used here. Nevertheless, some of its problems should be acknowledged: First, the frequency of votes on which individual voting behaviour is observable and for which the Rice Index can thus be calculated varies widely between countries. ${ }^{40}$ Accordingly, Rice scores are more representative of everyday legislative business in some countries than in others. For countries with relatively few roll-call votes, the question is whether cohesion in these votes differs systematically from that in non-recorded votes. ${ }^{41}$ On the one hand, we can interpret recorded votes as a disciplining device used by the PPG leadership so that unity should be higher. ${ }^{42}$ On the other hand, roll-calls are often called by parties trying to embarrass competitors who are expected to be internally divided so that unity should be lower. ${ }^{43}$ A second problem is that not all authors exclude free votes when calculating Rice scores, even though such votes decrease the validity of the reported values. ${ }^{44}$ Third, existing data in the literature are based on different operational decisions as to how to treat abstentions and non-votes, even though most authors follow Rice in simply ignoring these votes. Fourth, the construction of the Rice Index may lead to a systematic overestimation of small and relatively divided parties. ${ }^{45}$

The most fundamental decision on case selection is limiting the analysis to parliamentary democracies (see above). Furthermore, the systematic relationships between institutional characteristics and party unity can be assessed only if the party system of a country is reasonably settled and stable. For this reason, Eastern European countries are not included here. This limits the regional focus on Western Europe and the Anglo-Saxon Westminster democracies. Within this group, case selection is restricted by the availability of data. Despite this restriction, data for 11 countries could be found which cover rather nicely the institutional variance among Western democracies. ${ }^{46}$ The exact periods covered and the number of observations available for each country are displayed in Table 1.

\section{LEVELS OF PARTY UNITY IN 11 PARLIAMENTARY DEMOCRACIES}

Table 2 offers descriptive information on party unity in the 11 countries studied here. The unity scores are averaged on the system level and relate to the $1990 \mathrm{~s} .{ }^{47}$ If data for more than one legislative period were available, the numbers are averages.

First, average party unity is very high for all surveyed countries except Finland, especially when compared with presidential systems. ${ }^{48}$ Second, 
TABLE 1

PERIODS COVERED BY ROLL-CALL DATA

\begin{tabular}{|c|c|c|c|}
\hline & $\begin{array}{r}\text { Period(s) } \\
\text { Covered }\end{array}$ & $\begin{array}{l}\text { Period for } \\
\text { Calculating } \\
\text { Country } \\
\text { Averages }\end{array}$ & $\begin{array}{c}\text { Average Number of Observations } \\
\text { (Party Averages/Total Number } \\
\text { of Data Points) }\end{array}$ \\
\hline Austria & 199497 & 199497 & $5 / 10$ \\
\hline Australia & 199698 & 199698 & $3 / 3$ \\
\hline Canada $^{\mathrm{a}}$ & 199497 & 199497 & $4 / 4$ \\
\hline Denmark & 199096 & 199096 & $8 / 50$ \\
\hline Finland & $195154 ; 199596$ & 199596 & $7 / 12$ \\
\hline Germany & 194990 & 198090 & $4 / 35$ \\
\hline Iceland & 199596 & 199596 & $6 / 6$ \\
\hline New Zealand & $1990 \quad 94$ & $1990 \quad 94$ & $2 / 4$ \\
\hline Norway $^{\mathrm{b}}$ & 198194 & 199094 & $6 / 83$ \\
\hline Sweden $^{c}$ & $1969 ; 199495$ & $1994 \quad 95$ & $7 / 12$ \\
\hline $\mathrm{UK}^{\mathrm{d}}$ & $1945 \quad 2001$ & 19922001 & $2 / 25$ \\
\hline
\end{tabular}

${ }^{a}$ The numbers for Canada exclude the two person PPG of the Progressive Conservatives.

${ }^{\mathrm{b}}$ The numbers for Norway exclude the one person PPG of the Liberals during the session 199394.

${ }^{\mathrm{c}}$ The 1969 data from Sweden appears in Figure 2 but are not used in the regression models.

${ }^{\mathrm{d}}$ The data for the UK cover both major parties for the period 194579 and only the party in government after 1979.

Sources: Data for Austria are from W.C. Müller et al., Die österreichischen Abgeordneten (Vienna: WUV Universitätsverlag, 2001), p.250; data for Australia, Canada and New Zealand are from John Carey, personal communication; data for Denmark are from A. Skjaeveland, 'Party Cohesion in the Danish Parliament', Journal of Legislative Studies, 7 (2001), Table 3; data for Finland, Iceland and Sweden are from T.K. Jensen, 'Party Cohesion', in P. Esaiasson and K. Heidar (eds.), Beyond Westminster and Congress (Columbus, OH: Ohio State University Press, 2000), Table 9.1; data for Germany are from T. Saalfeld, Parteisoldaten und Rebellen. Fraktionen im Deutschen Bundestag 19491990 (Opladen: Leske \& Budrich, 1995), Tables 6.16 .3 and P. Schindler, Datenhandbuch zur Geschichte des Deutschen Bundestages 1949 bis 1999 (Baden Baden: Nomos, 1999), p.1784; data for Norway are from W.R. Shaffer, Politics, Parties, and Parliaments. Political Change in Norway (Columbus, OH: Ohio State University Press, 1998); data for the UK were calculated by the author based on data in P. Norton, Dissension in the House of Commons (London: Macmillan, 1975), P. Norton, Dissension in the House of Commons, 19741979 (Oxford: Clarendon Press, 1980), P. Cowley, Revolts and Rebellions. Par liamentary Voting under Blair (London: Politico's, 2002), P. Cowley and P. Norton, 'Rebels and Rebellions: Conservative MPs in the 1992 Parliament', British Journal of Politics and Inter national Relations, 1 (1999), pp.84 105, P. Cowley and M. Stuart, 'In Place of Strife? The PLP in Government, 1997 2001', Political Studies, 51 (2003), pp.1 18, and personal communi cation with Philip Cowley.

there is some variation between countries. Whereas unity is above 99 points for Denmark and the UK, it only reaches values between 94.75 and 96.6 for New Zealand ${ }^{49}$, Sweden and Germany. Finland, with 88.63, displays far lower unity than the other systems.

The standard deviations in Table 2 show that the degree of variance between parties also differs from one country to another. Whereas the unity of all parties is fairly similar in Australia, Denmark, New Zealand and the $\mathrm{UK}$, the variance between parties is fairly large in Finland, Germany and 
TABLE 2

MEAN PARTY UNITY IN THE 1990s

\begin{tabular}{lccc}
\hline & $\begin{array}{c}\text { Number of } \\
\text { PPGs }\end{array}$ & $\begin{array}{c}\text { Mean Party } \\
\text { Unity }\end{array}$ & $\begin{array}{r}\text { Standard } \\
\text { Deviation }\end{array}$ \\
\hline Austria & 5 & 98.33 & 1.71 \\
Australia & 3 & 99.00 & 0.00 \\
Canada & 4 & 98.25 & 1.26 \\
Denmark & 8 & 99.83 & 0.09 \\
Finland & 7 & 88.63 & 2.59 \\
Germany $^{\mathrm{a}}$ & 4 & 96.60 & 1.97 \\
Iceland & 6 & 96.93 & 2.84 \\
New Zealand & 2 & 94.75 & 0.35 \\
Norway & 6 & 98.72 & 0.56 \\
Sweden & 7 & 96.57 & 1.51 \\
UK & 2 & 99.31 & 0.22 \\
All systems & 5 & 96.76 & 3.75 \\
& 11 & 97.07 & 3.16 \\
\hline
\end{tabular}

${ }^{\mathrm{a}}$ The numbers for Germany refer to the 1980 s as more recent data are not available.

${ }^{\mathrm{b}}$ The first line refers to the party averages used, the second line to the country averages. Sources as in Table 1 .

Iceland. Finally, the party averages used so far conceal considerable variation over time. Figure 2 therefore treats the unity of a party in a single parliamentary session or term as the unit of analysis. ${ }^{50}$ All available data since 1945 are included. The large variance in Germany and Sweden is particularly striking. For Sweden, only data for two electoral periods separated by 25 years are available, so this variation has not been analysed in detail. For Germany, Thomas Saalfeld found and explained a clear increase of unity over time, especially for centre-right parties. ${ }^{51}$ Again, the variance is extremely low for Denmark and the UK, even though data are available for several periods.

\section{TESTING THE HYPOTHESES}

We now turn to testing the hypotheses derived from my model with the available data. The depth of the empirical testing differs due to the number of cases. Theoretically, all hypotheses apply ceteris paribus so that other variables would have to be controlled for. Unfortunately, there are not enough observations to use multivariate models for the first two groups of variables, which have to be tested using system averages. If instead party averages or even scores of individual parties during specific periods were used, the results would be biased because the different number of observations would practically result in weighting institutional factors prevalent in countries with many observations. ${ }^{52}$ Therefore, tests of the first two groups of hypotheses 


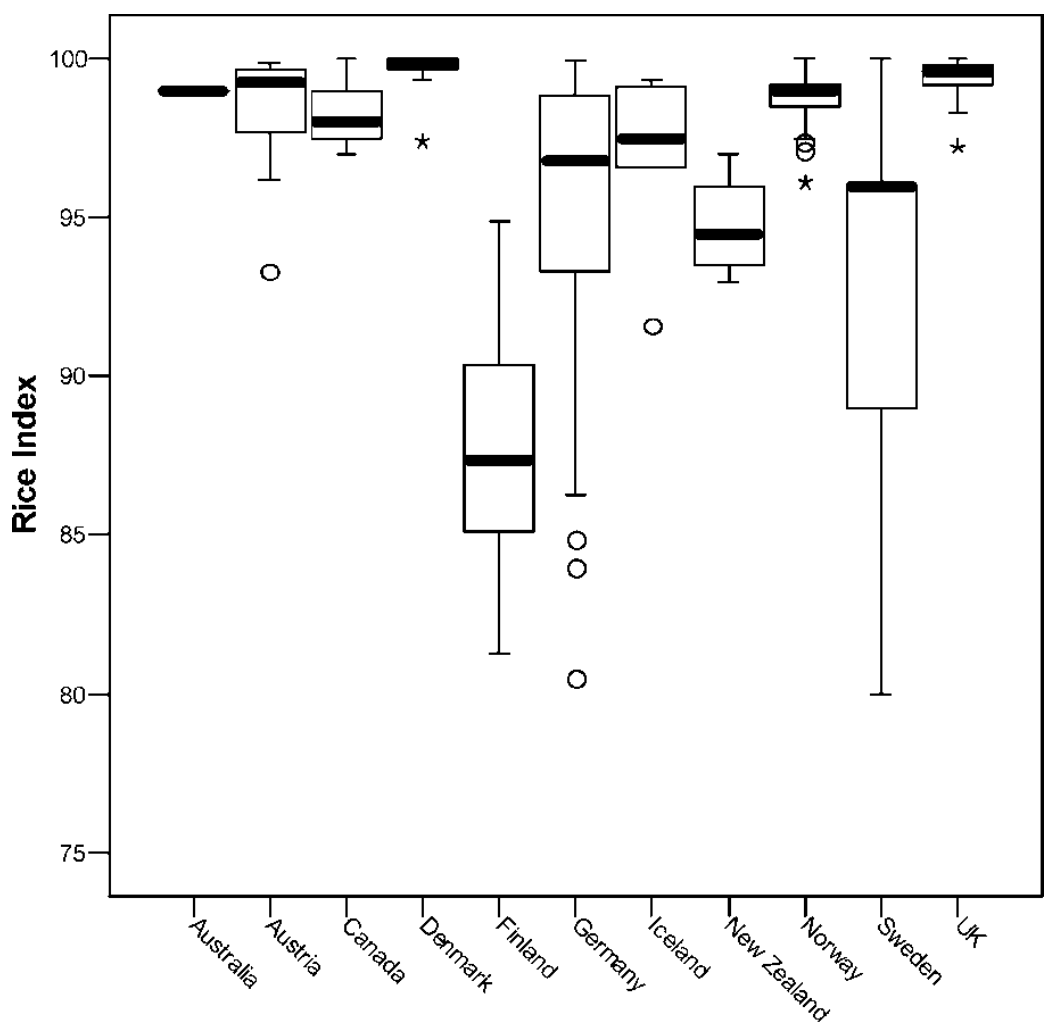

The symbol ${ }^{\circ}$ indicates a deviation of $1.5-3$ times the width of the box; ${ }^{*}$ indicates a deviation of more than three times the width of the box. The number of observations for each country is given in the last column of Table 1 . Sources as in Table 1.

are limited to bivariate relationships between average party unity in a country during the 1990s and the institutional characteristics of a country. ${ }^{53}$

The third group of independent variables varies both between parties and over time so that scores for individual parties during a specific period of time can be used as the unit of analysis. ${ }^{54}$ Overall, it was possible to gather 239 observations, which allows the use of a multivariate regression model. ${ }^{55}$

\section{Hypotheses with Regard to the Electoral System}

Lars Bille distinguished six categories of the central control over candidate nominations for parliamentary elections. ${ }^{56}$ Owing to the small number of 
cases, I further aggregate his categories. Central control is classified as high when the central party leadership can select candidates directly, or proposals from the local or regional level have to be approved. In all other cases, central control is considered low.

In line with hypothesis 1.1 , average party unity is higher if the central party leadership plays a formally guaranteed role in candidate selection. The average Rice Index for this group of countries is 98.19 , as compared with 96.65 when candidates are selected completely at the sub-national level or by party members. When differences between parties within countries are taken into account by using party averages instead of country averages, the difference is even larger (98.00 for high central control versus 96.09 for low control) and reaches statistical significance at the 10 per cent level. ${ }^{57}$ High centralised control over candidate selection thus is indeed associated with higher party unity.

Following Paul Mitchell, electoral systems can be put into three categories with regard to the incentives they offer for pursuing personal vote strategies. ${ }^{58}$ These incentives are lowest for party-centred systems [closed-list proportional representation (PR), additional member systems and formally open but in practice hard-to-change lists], followed by intermediate systems that allow for direct sanctioning of an MP by the voters but do not include intra-party competition (single-member simple plurality, alternative vote, double-ballot systems). Incentives for pursuing a personal vote are highest in candidatecentred systems in which candidates can be elected only on the basis of votes given to them personally in competition with members of their own party [genuinely open-list PR, single transferable vote (STV)].

Hypothesis 1.2 gains little support from the data. Average party unity in candidate-centred systems is 94.23 points and as such clearly lower than for the intermediate systems (97.83) and party-centred systems (97.60), but the variance within this group is huge. The group comprises both Finland with the lowest and Denmark with the highest average Rice score in the study. This extreme spread indicates that a candidate-centred electoral system is not a sufficient condition for dissenting voting behaviour by deputies, but it also indicates that low unity is at least not institutionally precluded. It is interesting to observe that, while intermediate and party-centred systems are very similar with regard to mean party unity, the latter group displays by far the least variance of all three groups, with a standard deviation of 0.98 as compared with 2.10 for intermediate and 7.92 for candidate-centred systems. As expected theoretically, this institutional configuration places rather rigid constraints on deputies.

\section{Hypotheses with Regard to Structural Dependence}

Unfortunately, the operationalisation of the various sorts of structural dependence faced by deputies is difficult. The comparative literature at this point 
only offers more or less close approximations of the concepts to be measured. Therefore, the results in this section remain preliminary and may change when more direct measures become available.

Hypothesis 2.1 expects a negative relationship between individual resources of MPs and party unity. We can distinguish between directly policy-relevant resources on the one hand and financial and organisational resources on the other hand. I use the individual right to initiate bills as an indicator of the first and construct a composite index of the second. This additive index is based on data from the Inter-Parliamentary Union (IPU) on individual access to: (1) secretarial services; (2) research and information services; and (3) office space. ${ }^{59}$ The comparison of means shows the expected difference: party unity in systems with personal initiative of MPs reaches an average value of 96.61, 1.69 points lower than in the other group. The difference is not statistically significant, though, and the variance in the first group is large. Also in line with theoretical expectations, unity in systems offering deputies high financial and organisational resources is 2.21 points lower than in the other group. ${ }^{60}$ Again, the difference does not reach customary levels of statistical significance, probably due to the high variance in the group with high individual resources.

Hypothesis 2.2 expects a positive relationship between party unity and a PPG leadership's control over the personal advancement of deputies. To operationalise the latter I use the process of recruitment for cabinet ministers. Expert judgement of the importance of the PPG leadership in this process exists only for some countries in the study; data are missing for Australia, Canada and New Zealand. The empirical results run counter to the hypothesis. Average party unity is 1.63 points lower in countries in which the PPG leadership plays an important role; again the difference is not statistically significant. ${ }^{61}$ Alternatively, the percentage of ministers recruited from within the PPG can be used as a proxy for the control the PPG leadership can exert over personal advances. Here the correlation of 0.274 is in line with theoretical expectations, even though not significant. ${ }^{62}$ Overall, hypothesis 2.2 gains only limited support here which may be due to the proxies used. A more thorough analysis would have to include data on advancement within the PPG and within the hierarchies of parliament and parliamentary committees as well. ${ }^{63}$

According to hypothesis 2.3 , party unity should be higher the more severe are the possible sanctions at the disposal of the PPG leadership and the more credible is the use of these sanctions. Testing this hypothesis is particularly difficult because no comparative data are available on the sort of sanctions the PPG leadership could use and, even less, the credibility of their use. As a proxy, I use the right of a PPG to recall its members from parliamentary committees without the involvement of parliament as a whole. The empirical data contradict the original hypothesis even though the finding is not 
statistically significant. Systems in which the PPGs are free to recall committee members at will display an average party unity of $96.39,1.86$ points lower than the other group. ${ }^{64}$ Again, a more detailed analysis based on better data would be valuable.

Hypothesis 2.4, finally, expects a negative relationship between party unity and the strength of parliamentary committees. I use one variable from each of the two dimensions of committee strength discovered by Mattson and Strøm for Western European parliaments: the right of committees to rewrite bills and their right to compel witnesses. ${ }^{65}$ These two variables are at least roughly representative for the two main theoretical perspectives on parliamentary committees, the gains-from-trade approach and the informational approach.

As expected, average party unity is lower in parliaments where committees are free to rewrite bills. The difference of 2.13 , while not statistically significant, is among the largest discovered for the system-level hypotheses. ${ }^{66} \mathrm{In}$ contrast to the hypothesis, the relationship between the right to compel witnesses and party unity is positive. The average values are 99.08 for parliaments in which this right exists compared with 96.62 for the other group. The difference of 2.46 points is large but not statistically significant. We should be cautious about this finding for two reasons. First, only two parliaments in the sample (Austria and Denmark) grant this power to their committees. Second, the right to compel witnesses refers only to one aspect of the strength of committees as arenas for information gathering. Better indicators would be necessary for a more meaningful test of this hypothesis.

Table 3 summarises the results from the bivariate tests of hypotheses 1.1 2.4. Most of the institutional hypotheses are supported as they have the predicted sign. Contradictory findings appear mainly for variables for which problematic proxies had to be used. Despite the general lack of statistical significance, I interpret these results as justifying additional research in the directions indicated here.

\section{Hypotheses with Regard to Situational Resources}

For the third group of variables, the number of cases is large enough to use multivariate regression models. The independent variables are government participation with at least one cabinet minister, the relative size of the PPG as the percentage of its seats in parliament, the percentage of seats held by all government parties, and the ideological distance of a PPG from the closest other party on the left-right-dimension as created by Ian Budge and his colleagues on the basis of party manifestos. ${ }^{67}$

In total, I estimate four models (see Table 4). The first model introduces only the four independent variables relating to the third group of hypotheses. Model II includes country dummies, and models III and IV specify model II by 
TABLE 3

THE EFFECTS OF INSTITUTIONAL VARIABLES ON PARTY UNITY IN 11

PARLIAMENTARY DEMOCRACIES

\begin{tabular}{|c|c|c|c|}
\hline Hypothesis & Independent Variable & $\begin{array}{c}\text { Expected } \\
\text { Relationship }\end{array}$ & Observed Relationship \\
\hline 1.1 & $\begin{array}{l}\text { Central control over } \\
\text { candidate nomination }\end{array}$ & + & $\begin{array}{l}+ \text { (country averages }) \\
+(\text { party averages })\end{array}$ \\
\hline 1.2 & $\begin{array}{l}\text { Incentives to cultivate a } \\
\text { personal vote }\end{array}$ & - & 0 \\
\hline 2.1 & $\begin{array}{l}\text { Control of PPG leadership } \\
\text { over intra parliamentary } \\
\text { resources }\end{array}$ & + & $\begin{array}{l}+(\text { private member initiative }) \\
+ \text { (financial and } \\
\quad \text { organisational resources })\end{array}$ \\
\hline 2.2 & $\begin{array}{l}\text { Control of PPG over personal } \\
\text { advancement of MPs }\end{array}$ & + & $\begin{array}{l}- \text { (PPG control over } \\
\quad \text { selection of ministers }) \\
+(\% \text { ministers selected from } \\
\quad \text { parliament })\end{array}$ \\
\hline 2.3 & $\begin{array}{l}\text { (Potential) sanctions at the } \\
\text { disposal of PPG leadership }\end{array}$ & + & - (recall from committee) \\
\hline 2.4 & $\begin{array}{l}\text { Strength of parliamentary } \\
\text { committees }\end{array}$ & - & $\begin{array}{l}- \text { (rewrite authority) } \\
+ \text { (right to compel witnesses) }\end{array}$ \\
\hline
\end{tabular}

Notes: Only the difference between party averages for hypothesis 1.1 is statistically significant at the 10 per cent level. All other relationships fail to reach customary levels of statistical significance, which may be due to the small number of cases.

The second test of hypothesis 2.1 excludes Iceland due to missing data.

The first test of hypothesis 2.2 excludes Australia, Canada and New Zealand due to missing data.

stepwise exclusion of insignificant variables. Owing to heteroskedasticity, robust standard errors are used in estimating all models.

Model I lends support to hypothesis $3.1 \mathrm{~b}$, according to which government parties are less unified than opposition parties. This finding runs counter to the common view that being in government helps to uphold party unity, be it for reasons of positive incentives or because of disciplining devices such as the vote of confidence. The empirical findings contradict hypothesis 3.2, finding larger parties to be significantly more unified, even though the substantive effect is low. As expected, unity is found to be significantly higher when the margin of the government over the opposition decreases. In this case, government parties need to be unified in order to win votes and opposition parties have incentives to act in a unified way, hoping to win some votes with the help of government dissenters. Finally, in line with hypothesis 3.4, the unity of a PPG is higher when the policy distance to the closest PPG increases. In such cases it is more difficult for dissatisfied deputies to find attractive alternatives in other PPGs, both on single policy decisions and more generally as an exit option. The substantive effect is relatively small and the results suffer from the restriction to the left-right dimension. None the less, this finding lends support to the idea that unity depends on the availability of attractive alternatives. 
TABLE 4

THE EFFECT OF SITUATIONAL RESOURCES ON PARTY UNITY IN 11 PARLIAMENTARY DEMOCRACIES

\begin{tabular}{|c|c|c|c|c|}
\hline & I & II & III & IV \\
\hline Constant & $104.736(0.876)^{* * *}$ & $98.848(2.098)^{* * *}$ & $98.176(0.241)^{* * *}$ & $98.308(0.235)^{* * *}$ \\
\hline Government party & $-1.051(0.538)^{*}$ & $-0.631(0.392)$ & $-0.683(0.383)^{*}$ & \\
\hline PPG size & $0.041(0.013)^{* * *}$ & $0.028(0.015)^{*}$ & $0.024(0.012)^{* *}$ & $0.020(0.0086)^{* *}$ \\
\hline Margin of government & $-0.159(0.023)^{* * *}$ & $-0.023(0.033)$ & & \\
\hline Ideological distance & $0.025(0.013)^{*}$ & $0.022(0.014)^{*}$ & $0.021(0.012)^{*}$ & \\
\hline Australia & & $1.033(0.790)$ & & \\
\hline Austria & & $0.474(0.951)$ & & \\
\hline Denmark & & $1.518(0.972)$ & $1.353(0.186)^{* * *}$ & $1.193(0.152)^{* * *}$ \\
\hline Finland & & $-10.028(1.351)^{* * *}$ & $-10.798(1.097)^{* * *}$ & $-11.129(1.159)^{* * *}$ \\
\hline Germany & & $-3.278(1.053)^{* * *}$ & $-3.803(0.826)^{* * *}$ & $-3.827(0.882)^{* * *}$ \\
\hline Iceland & & $-0.825(1.307)$ & & \\
\hline New Zealand & & $-3.938(1.174)^{* * *}$ & $-4.445(0.839)^{* * *}$ & $-4.534(0.869)^{* * *}$ \\
\hline Norway & & $0.429(0.897)$ & & \\
\hline Sweden & & $-1.174(0.975)^{*}$ & $-2.057(.574)^{* * *}$ & $-2.023(0.469)^{* * *}$ \\
\hline UK & & $0.144(0.834)$ & & \\
\hline$R^{2}$ & 0.277 & 0.630 & 0.621 & 0.608 \\
\hline$F$ & $12.17^{* * *}$ & $18.61^{* * *}$ & $34.40^{* * *}$ & $47.06^{* * *}$ \\
\hline$N$ & 239 & 239 & 239 & 239 \\
\hline
\end{tabular}

Notes: Standard errors in parentheses; robust standard errors are used due to heteroskedasticity.

For models III and IV, variables are excluded by stepwise regression if significance is above 0.1 (model III) and 0.05 (model

IV), respectively.

${ }^{*} p<0.10,{ }^{* *} p<0.05,{ }^{* * *} p<0.01$. 
The explanatory power of the model is modest as it accounts for only 27.7 per cent of the variance in the dependent variable. This is hardly surprising as none of the institutional variables discussed in the last section can be included due to the methodological problems mentioned above. Some of the unexplained variance could probably be captured by these system-level institutional variables, some may be due to factors completely outside the scope of my model, such as role perceptions of deputies, differing conceptions of representation and other characteristics of party cultures. These variables cannot be dealt with individually here. As an approximation, though, we can expect that these factors taken together lead to country-specific levels of party unity. Therefore, I introduce dummy variables for all the countries except Canada in model II. ${ }^{68}$

Two variables from model I, government status and the margin of the government over the opposition, retain their respective signs but fail to reach statistical significance in model II. ${ }^{69}$ The other two variables remain significant with the same sign, but decrease in both substantial impact and significance. Among the country dummies, some highly significant effects are found, indicating that there is something specific about these countries that is not captured by the situational factors. Significantly lower unity is found in Sweden, Germany, New Zealand and, particularly, Finland. Some thoughts on these cases are offered towards the end of this section.

The fit of the model including country dummies is much better, capturing 63 per cent of the variance. This increase shows that it is worthwhile to investigate in-depth how the country dummies can be interpreted substantively. The bivariate relationships analysed above offer some hints as to how country labels could at least partly be substituted by institutional configurations.

Since many country dummies in model II are insignificant, I exclude insignificant variables by a backward elimination procedure. Starting from the full model, the least significant independent variable is dropped from the model provided it is not significance at the 10 per cent level. This process is repeated until all remaining variables are significant at least at the 10 per cent level. This procedure leads to model III.

Now government status becomes significant again. The coefficients of PPG size and ideological distance increase in significance. Among the country dummies, those already significant in model II all reach the 1 per cent level of significance. Only the dummy for Denmark becomes significant for the first time, indicating that the unity of Danish parties is significantly higher than could be expected from the situational factors in the model.

Finally, model IV presents the results from the backward elimination procedure described above when the threshold for elimination is lowered to the more demanding 5 per cent level. Now only one of the situational variables remains significant: Again in contrast to the prevalent view in the literature 
expressed in hypothesis 3.2, larger parties are found to be more unified than smaller ones. ${ }^{70}$ All the dummies from model III reappear with similar coefficients and significances.

What conclusions can be drawn from the multivariate models? First, throughout the models government participation has a negative effect on party unity, even though its statistical significance differs. Overall, this sheds doubt on the frequent argument that government parties are better equipped to extract party unity through positive incentives or sanctions. Instead, the need to take a position on divisive issues and possibly voting for tough compromises with coalition partners should be considered as important strains on party unity in legislative voting. Second, the constant finding of a positive relationship between PPG size and unity requires explanation. One reason could be the generally high levels of unity throughout all systems in this analysis. When most deputies toe the party line almost all the time, a small number of defectors or even a single defector is more visible in small parties and depresses their Rice score more drastically than would be the case in larger parties. ${ }^{71}$ Third, the negative effect of the government's margin in model I disappears when country dummies are introduced. Fourth, the hypothesis on ideological distance is supported in most models even though its substantive effect is rather small. Fifth, as discussed below, the large improvement of model fit when country dummies are introduced points to the importance of tying these differences between countries to relevant variables such as specific institutional regimes. ${ }^{72}$ Finally, the fact that even the models with country dummies leave almost 40 per cent of the variance in the dependent variable unexplained underscores the role of idiosyncratic factors affecting party unity, such as time-specific factors, personal characteristics of actors and unpredictable events.

The question remains open as to how the country-specific effects discovered in the multivariate models can be explained. Unfortunately, this analysis cannot reveal whether these effects are due to the institutional factors analysed above or to factors outside my theoretical model. None the less, the respective institutional regimes are at least compatible with the lower unity observed in Germany and particularly Finland. Finnish candidates for parliament are nominated at the sub-national level, often with direct involvement of party members. The electoral system is candidate-centred, which further decreases the control the central party leadership can exercise. On the parliamentary stage, committees play an important role in policy-making and many ministers are recruited from outside parliament, which indicates that the PPG leadership is unable to monopolise personal advancement into executive office. Similarly, the German electoral system restricts centralised control by the party leadership as candidates are nominated at the local or regional (Land) level and half the deputies are elected in single member districts. On the 
parliamentary stage, committees are influential, and dissenting behaviour often is not punished by the PPG leadership. ${ }^{73}$ In addition, the German case may deviate from the other findings because of the longer time period covered, which includes the early days of the Federal Republic when unity was lower, especially in the newly founded Christian Democratic and liberal parties.

The finding for New Zealand probably results from the unusual situation of deputies acting in a highly uncertain environment on the eve of a major reform of the electoral system, which was changed from the classic firstpast-the-post system to a mixed-member proportional system in 1996. Prior to this change, political entrepreneurs were eager to found new parties and place themselves in attractive positions at the centre of the changing party system. ${ }^{74}$ In that situation, many of the institutional incentives otherwise suggesting high unity were ineffective. Judging from the institutional regime, one would expect party unity in New Zealand to rise again after the party system settles down.

My model does not offer an unequivocal explanation for the significantly lower level of party unity in Sweden. Candidate nomination in Sweden takes place at the regional level and directly involves party members. In addition, parliamentary committees are strong with regard to policy-making. Many of the other institutional variables would lead us to expect high unity, though, so that other factors would have to be considered to explain the slightly lower unity in Sweden.

Finally, the significantly higher levels of unity observed in Denmark in models III and IV are problematic from the perspective of my model, as the institutional context, especially the open-list PR electoral system, offers opportunities for dissenting behaviour. One limitation may be the comparatively low level of staff support enjoyed by Danish deputies, which was until 1997 completely controlled by the PPGs. ${ }^{75}$ A detailed country study of the Danish parliament found the absence of disagreement within parties and a strong moral commitment to the party to be the main reasons for high unity, indicating that the institutional variables discussed above may not be the most important factors in the Danish case. ${ }^{76}$

\section{SUBSTANTIVE IMPORTANCE AND IMPLICATIONS FOR FUTURE RESEARCH}

Given the fact that the level of party unity is generally high, with average Rice scores of above 95 points in almost all countries studied here, the question might arise of how substantively important is this research and what implications it has for legislative studies more broadly. Three arguments underscoring the substantive importance of this research question are put forward before commenting on some implications. 
First of all, even a small number of dissenters can endanger the ability of a parliamentary majority to pass its agenda if the government's margin over the opposition is sufficiently small. A Rice score of 96 points, for example, implies that on average the government cannot be sure of its parliamentary majority if it holds less than 51.02 per cent of the seats. ${ }^{77}$ In my sample alone, this is the case on seven occasions involving 33 parties. Furthermore, the reported unity scores are averages, implying that unity is sometimes lower. If we assume that the number of dissenters will sometimes be twice as high as the average, the Rice score for individual votes will at times go down to 92 points. In this situation, governments holding less than 52.08 per cent of the seats are in danger, which is the case in an additional three situations involving nine parties in the sample. When we look at all cabinets in 17 Western European democracies since 1945, we find 31 majority cabinets holding less than 51.02 per cent of the seats and a total of 49 majority cabinets controlling less than 52.08 per cent. ${ }^{78}$ Thus, even seemingly innocuous deviations from party unity may have important consequences.

Second, the fear of low party unity may affect the choices of political actors in the context of coalition formation. William Riker argued, more than 40 years ago, that expected defections from backbenchers might keep party leaders from forming minimum size coalitions, which they would otherwise prefer. ${ }^{79}$ I expect that quite a few coalitions never came to be because of expected problems with party unity.

Third, we should not forget that the countries studied here are established parliamentary systems of government and display higher and more stable levels of party unity than many younger and less consolidated party systems, especially in Eastern Europe. In these systems, institutional means to induce party unity may be of much more immediate concern to political actors and institutional designers. In this context, the long-term effect of such institutional mechanisms in Western democracies may provide valuable hints on potential institutional equilibria.

These arguments provide good reasons to take the result of this study seriously. It is useful to highlight some perspectives for legislative studies that emerge from the arguments above. First, it would be important to look behind the aggregate measures used here to discover variations in party unity between votes that may be lost in the process of aggregation. Second, we should look at the effects lower party unity has on policy outputs. Does the government lose parliamentary votes because of dissenters within its own rank and file? As the British case indicates, governments occasionally lose important votes despite large margins and near-perfect average unity scores. Even more importantly (though harder to investigate), does the government forgo legislative projects because it fears losing the vote? It is likely that much of the limiting effects of low unity will not be visible because the party leadership anticipates problems and never puts divisive issues to a vote. 
Third, interesting questions emerge with regard to the effects of intra-party politics on coalition formation and termination. Do party élites forgo certain coalitions because they are afraid of dissenters within their own party? Do coalitions fail because of backbencher dissent? These questions have only recently been taken up by coalition research but offer valuable perspectives.

Finally, the findings of this study should be seen in context with studies of party unity in new democracies. ${ }^{80}$ While county-specific differences are likely to lead to somewhat different results in other countries, these findings offer indications of how various institutional settings are likely to affect party unity once the party system has consolidated. Some institutions create more incentives for unified voting behaviour than others. These findings are important for institutional designers as well as for scholars interested in issues of representation, party democracy and democratic theory.

\section{CONCLUSION}

This article has presented the broadest comparative analysis thus far of legislative party unity in established parliamentary democracies on the basis of rollcall votes. Even though the empirical findings suffer from problems of data quality and at times the small number of cases, two general results stand out: party unity varies both between different parliamentary democracies and within individual countries. An institutionalist model was offered to explain these differences as the result of individual decisions taken by rational deputies reacting to institutional incentives and constraints in their respective environments and to time-specific resources. Hypotheses derived from this model, many of which are commonplace in the literature, were tested against roll-call data from 11 established parliamentary democracies. At the system level, centralised control over candidate nomination and over various sorts of intra-parliamentary resources as well as the strength of parliamentary committees with respect to policy decisions emerged as promising explanatory factors. With regard to time-specific resources, the most interesting finding was the negative effect of government participation on party unity. This result sheds doubt on recent arguments in the literature claiming that government parties have better opportunities for disciplining their PPGs through incentives and sanctions. In my sample at least, this argument does not hold. As an alternative explanation I argued that government PPGs display lower unity because they are forced to take a stand on divisive issues and have to broker compromises, alienating some deputies. A second interesting finding is that the heterogeneity often attributed to larger PPGs does not inhibit their ability to act in unison on roll-call votes. Instead, increased size even has a positive effect on party unity, which is explained by the larger weight of individual dissent on the overall unity score in smaller parties. 
Overall, party unity is a more complex phenomenon than suggested by the often-used unitary actor assumption. Therefore, the recently increasing interest in its study, especially in an explicitly comparative perspective, and efforts to create new data sets on thus far unstudied countries, are very valuable. From this contribution, I have suggested that differences within the group of parliamentary democracies should be given more emphasis than they have received thus far, and offered some promising areas of study. Studies along the lines pursued and proposed here could help not only to assess the empirical tenability of the unitary actor assumption, but could also more generally contribute to our understanding of the effects of institutional rules on actors' behaviour in parliaments.

\section{NOTES}

1. For the state of research on PPGs, see K. Heidar and R. Koole (eds.), Parliamentary Party Groups in European Democracies. Political Parties Behind Closed Doors (London: Routledge, 2000).

2. For policy decisions, see G. Tsebelis, Veto Players. How Political Institutions Work (Princeton, NJ: Princeton University Press, 2002); for coalition formation, see M. Laver and N. Schofield, Multiparty Government. The Politics of Coalition in Europe (Cambridge: Cambridge Univer sity Press, 1990).

3. H. Daalder, 'The Comparative Study of European Parties and Party Systems', in H. Daalder and P. Mair (eds.), West European Party Systems (London: Sage, 1983), pp.1 27; R.S. Katz and P. Mair, 'Introduction', in R.S. Katz and P. Mair (eds.), Party Organizations. A Data Hand book (London: Sage, 1992), pp.1 20.

4. See the special issue of this journal on cohesion and discipline in parliaments [Journal of Leg islative Studies, 9(4), 2003] and some papers presented to the workshop on intra party politics at the 2005 ECPR Joint Sessions of Workshops in Granada.

5. In the terminology of Hazan's recent conceptual overview, I follow an institutional approach instead of a sociological one that would focus on role perceptions of actors, socialisation, cognitive maps and the like; R. Y. Hazan, 'Does Cohesion Equal Discipline?', Journal of Legislative Studies, 9 (2003), pp.1 11.

6. Hazan, 'Does Cohesion Equal Discipline?'; S. Bowler, D.M. Farrell and R.S. Katz, 'Party Cohesion, Party Discipline, and Parliaments', in S. Bowler, D.M. Farrell and R.S. Katz (eds.), Party Discipline and Parliamentary Government (Columbus, OH: Ohio State University Press, 1999), pp.3 22. Note that this usage differs from the terminology originally introduced by Ozbudun, who used 'cohesion' for the observable behaviour while using 'discipline' in the way it is employed here. He did not have a special term for purely preference induced unity; see E. Ozbudun, 'Party Cohesion in Western Democracies', Sage Professional Papers in Com parative Politics, 1 (1970), pp.303 88, p.305.

7. Ozbudun, 'Party Cohesion in Western Democracies'.

8. J.M. Carey, 'Political Institutions, Competing Principals, and Party Unity in Legislative Voting', Manuscript, Dartmouth College (http://www.dartmouth.edu/ jcarey/carey comp prin aug2004.pdf); J.M. Carey, 'Getting Their Way or Getting Into the Way?', paper presented at the APSA Meeting in Boston, August 2002.

9. S. Depauw, 'Government Party Discipline in Parliamentary Democracies: The Cases of Belgium, France and the United Kingdom in the 1990s', Journal of Legislative Studies, 9 (2003), pp.130 46; T.K. Jensen, 'Party Cohesion', in P. Esaiasson and K. Heidar (eds.), Beyond Westminster and Congress (Columbus, OH: Ohio State University Press, 2000), pp.210 36. 
10. Party unity is studied far more intensively in non parliamentary systems, especially with regard to the US Congress; for overviews, see M.P. Collie, 'Voting Behavior in Legislatures', in G. Loewenberg, S.C. Patterson and M.E. Jewell (eds.), Handbook of Legislative Research (Cambridge, MA: Harvard University Press, 1985), pp.471 518; N.W. Polsby and E. Schickler, 'Landmarks in the Study of Congress since 1945', Annual Review of Political Science, 5 (2002), pp.333 67. A recent quantitative study of voting behaviour also exists for the Swiss National Council, see P. Lanfranchi and R. Lüthi, 'Cohesion of Party Groups and Interparty Conflict in the Swiss Parliament', in S. Bowler, D.M. Farrell and R.S. Katz (eds.), Party Discipline and Parliamentary Government (Columbus, OH: Ohio State University Press, 1999), pp.99 120.

11. P. Norton, Dissension in the House of Commons (London: Macmillan, 1975); P. Norton, Dissension in the House of Commons, 19741979 (Oxford: Clarendon Press, 1980).

12. For Germany, see T. Saalfeld, Parteisoldaten und Rebellen. Fraktionen im Deutschen Bun destag 19491990 (Opladen: Leske + Budrich, 1995); for Norway, see B.E. Rasch, 'Elec toral Systems, Parliamentary Committees, and Party Discipline: The Norwegian Storting in Comparative Perspective', in S. Bowler, D.M. Farrell and R.S. Katz (eds.), Party Discipline and Parliamentary Government (Columbus, OH: Ohio State University Press, 1999), pp.121 140; for Denmark, see A. Skjaeveland, 'Party Cohesion in the Danish Parliament', Journal of Legislative Studies, 7 (2001), pp.35 56; for Belgium, see S. Depauw, 'Parliamentary Party Cohesion and the Scarcity of Sanctions in the Belgian Chamber of Representatives (1991 1995)', Res Publica, 41 (1999), pp.15 39; for Italy, see F. Ferrara, 'Frogs, Mice and Mixed Electoral Institutions: Party Discipline in Italy's XIV Chamber of Deputies', Journal of Legislative Studies, 10 (2004), pp.10 31.

13. D.R. Mayhew, Congress. The Electoral Connection (New Haven, CT: Yale University Press, 1974).

14. G.W. Cox and M.D. McCubbins, Legislative Leviathan. Party Government in the House (Berkeley, CA: University of California Press, 1993).

15. M. Hechter, Principles of Group Solidarity (Berkeley, CA: University of California Press, 1987).

16. Thus, my model combines the two approaches Bowler distinguished in the literature: the "two arena model' analysing the effects of the electoral on the parliamentary arena and the 'one arena model' focusing solely on incentives in the parliamentary arena; see S. Bowler, 'Parties in Legislatures. Two Competing Explanations', in R.J. Dalton and M.P. Wattenberg (eds.), Parties without Partisans (Oxford: Oxford University Press, 2000), pp.157 79.

17. Thus, I assume that the situational distribution of resources influences neither the structural dependence between deputies and their parties nor the institutional rules determining access to parliamentary seats. This assumption might be questionable for long term analyses but seems reasonable in a static analysis interested in the effects of institutions on actors' behaviour and not aimed at explaining institutional change.

18. See in particular Carey, 'Political Institutions, Competing Principals, and Party Unity in Legislative Voting'; Bowler et al., 'Party Cohesion, Party Discipline, and Parliaments'; Rasch, 'Electoral Systems, Parliamentary Committees, and Party Discipline'; Saalfeld, Parteisoldaten und Rebellen.

19. See W.C. Müller, 'Political Parties in Parliamentary Democracies: Making Delegation and Accountability Work', European Journal of Political Research, 34 (2000), pp.309 33.

20. L. Bille, 'Democratizing a Democratic Procedure: Myth or Reality?', Party Politics, 7 (2001), pp.363 80; G. Rahat and R.Y. Hazan, 'Candidate Selection Methods', Party Politics, 7 (2001), pp.297 322. Procedures sometimes vary between parties within the same country so that candidate selection is not a system level variable. These differences are taken into account in the empirical analysis.

21. Bille, 'Democratizing a Democratic Procedure: Myth or Reality?'

22. B. Cain, J. Ferejohn and M.P. Fiorina, The Personal Vote. Constituency Service and Electoral Independence (Cambridge, MA: Harvard University Press, 1987).

23. J.M. Carey and M.S. Shugart, 'Incentives to Cultivate a Personal Vote', Electoral Studies, 14 (1995), pp.417 39; R.S. Katz, 'Intraparty Preference Voting', in B. Grofman and A. Lijphart 
(eds.), Electoral Laws and Their Political Consequences (New York: Agathon Press, 1986), pp.85 103; P. Mitchell, 'Voters and Their Representatives', European Journal of Political Research, 37 (2000), pp.335 51.

24. Of course deputies can also cultivate a personal vote by means other than parliamentary voting, for example, through individual casework or direct intervention in favour of local interests.

25. P.F. Whiteley and P. Seyd, 'Discipline in the British Conservative Party', in S. Bowler, D.M. Farrell and R.S. Katz (eds.), Party Discipline and Parliamentary Government (Columbus, OH: Ohio State University Press, 1999), pp.53 71, p.56.

26. See Depauw, 'Parliamentary Party Cohesion and the Scarcity of Sanctions in the Belgian Chamber of Representatives' (also listing other possible sanctions).

27. E. Damgaard, 'How Parties Control Committee Members', in H. Döring (ed.), Parliaments and Majority Rule in Western Europe (Frankfurt: Campus, 1995), pp.308 25.

28. These two elements match the two predominant theoretical schools established in the study of committees in the US Congress. For the gains from trade school, see K.A. Shepsle and B.R. Weingast, 'Positive Theories of Congressional Institutions', Legislative Studies Quarterly, 19 (1994), pp.149 79; for the informational school, see K. Krehbiel, Information and Legislative Organization (Ann Arbor, MI: University of Michigan Press, 1991).

29. Strong committees do not automatically imply complete independence from the PPGs, though. Instead, various mechanisms exist that allow PPGs to control 'their' committee members; see Damgaard, 'How Parties Control Committee Members'.

30. Carey, 'Getting Their Way or Getting Into the Way?', p.23; Carey, 'Political Institutions, Competing Principals, and Party Unity in Legislative Voting', p.4; D. Diermeier and T.J. Feddersen, 'Cohesion in Legislatures and the Vote of Confidence Procedure', American Political Science Review, 92 (1998), pp.611 21; R.S. Katz, 'Party Government', in F.G. Castles and R. Wildenmann (eds.), Visions and Realities of Party Government (Berlin: De Gruyter, 1986), pp.31 71, p.63; Saalfeld, Parteisoldaten und Rebellen, p.271.

31. This argument with regard to large parties in Germany is made in passing by K. v. Beyme, Der Gesetzgeber. Der Bundestag als Entscheidungszentrum (Opladen: Westdeutscher Verlag, 1997), p.288. See also T. Bergman, W.C. Müller, K. Strøm and M. Blomgren, 'Democratic Delegation and Accountability: Cross national Patterns', in K. Strøm, W.C. Müller and T. Bergman (eds.), Delegation and Accountability in Parliamentary Democracies (Oxford: Oxford University Press, 2003), pp.109 220, p.128.

32. Carey, 'Getting Their Way or Getting Into the Way?', p.22; D. Dion, Turning the Legislative Thumbscrew. Minority Rights and Procedural Change in Legislative Politics (Ann Arbor, MI: University of Michigan Press, 1997), pp.47 55; classically E.E. Schattschneider, Party Gov ernment (New York: Rinehart and Company, 1942), p.95.

33. Bowler et al., 'Party Cohesion, Party Discipline, and Parliaments', p.13; Saalfeld, Parteisol daten und Rebellen, p.270.

34. At the same time, individual deputies probably have a stronger bargaining position under close margins and should be able to extract more concessions in exchange for their vote. Such concessions should be observable in qualitative studies of the decision making process within governing parties. At the parliamentary voting stage analysed here, such bargains should already be struck so that hypothesis 3.3 holds.

35. Saalfeld, Parteisoldaten und Rebellen, p.267; K. Heidar and R. Koole, 'Approaches to the Study of Parliamentary Party Groups', in K. Heidar and R. Koole (eds.), Parliamentary Party Groups in European Democracies (London: Routledge, 2000), pp.4 22, p.18.

36. See, for example, P. Svensson, 'Party Cohesion in the Danish Parliament during the 1970s', Scandinavian Political Studies, 5 (1982), pp.17 42; Saalfeld, Parteisoldaten und Rebellen, pp.55 60.

37. Another frequently used measure is the percentage of divisions witnessing some dissenting votes. Often the number of dissenters is also reported. These measures are used when dissent is so rare that small variations would be missed by the Rice Index. Examples include the work cited above on Denmark, Belgium and the British House of Commons.

38. S.A. Rice, Quantitative Methods in Politics (New York: Russell \& Russell, 1928). 
39. There is a debate in the literature on whether abstentions should not be treated as a milder version of dissent instead of being ignored; see Carey, 'Political Institutions, Competing Principals, and Party Unity in Legislative Voting'; Saalfeld, Parteisoldaten und Rebellen, pp.73 77; S. Hix, A. Noury and G. Roland, 'Power to the Parties: Cohesion and Competition in the European Parliament, 1979 2001', British Journal of Political Science, 35 (2005), pp.209 34.

40. See T. Saalfeld, 'On Dogs and Whips: Recorded Votes', in H. Döring (ed.), Parliaments and Majority Rule in Western Europe (Frankfurt: Campus, 1995), pp.528 65. Of the cases covered here, most votes are available for the British House of Commons in the period 198792 (1650 votes), the fewest for the German Bundestag from 1965 to 1969 (24 votes).

41. S. Hug, 'Selection Effects in Roll Call Votes', paper presented at the ECPR Joint Sessions of Workshops, Granada, 1419 April 2005.

42. Saalfeld, 'On Dogs and Whips: Recorded Votes'.

43. Lanfranchi and Lüthi, 'Cohesion of Party Groups and Interparty Conflict in the Swiss Parlia ment', p.106.

44. J.E. Owens, 'Explaining Party Cohesion and Discipline in Democratic Legislatures', Journal of Legislative Studies, 9 (2003), pp.12 40, pp. 16 17. Sometimes, a PPG leadership fearing low unity may decide to give a vote 'free' in order to avoid embarrassment. In this case, low unity scores on these votes are correctly interpreted as signs of disunity.

45. S.W. Desposato, 'Correcting for Small Group Inflation of Roll Call Cohesion Scores', British Journal of Political Science, 35 (2005), pp.731 44. For the data used in this article the correlation between the original scores and scores corrected using Carey's procedure derived from Desposato's argument is almost perfect $(r=0.999)$, so that the uncorrected scores are used in the analyses below; Carey, 'Getting Their Way or Getting Into the Way?'

46. Compare, for example, the positions of the included countries in Lijphart's two dimensional map of democracy; A. Lijphart, Patterns of Democracy (New Haven, CT: Yale University Press, 1999), p.248.

47. I exclude the Norwegian Liberals (1993 94), consisting of only one MP, and the Canadian Progressive Conservatives, consisting of only two deputies, who often disagreed. Numbers for Germany are averages over the 1980s because no data are available for the time since.

48. See Carey, 'Getting Their Way or Getting Into the Way?', Figure 1.

49. The low value for New Zealand is puzzling at first glance but can be explained by the immi nent change of the electoral system. Comment on this point is made more extensively towards the end of this article.

50. The periods over which Rice scores are aggregated differ. Scores refer to entire legislative periods in Austria, Germany and the UK and to yearly legislative sessions in Denmark and Norway. The periods for the other countries are 1 year (Finland, Iceland, Sweden), 2 years (Australia), 3 years with interruptions (Canada), and a combination of 3 years and 1 year (New Zealand).

51. Saalfeld, Parteisoldaten und Rebellen.

52. Carey, 'Getting Their Way or Getting Into the Way?', p.20.

53. The limits of bivariate tests have to be kept in mind when interpreting the results.

54. When unity scores are aggregated over periods shorter than an entire interelection period, the values on party size and ideological position are equal for more than one observation. Never theless, I stick to the short time periods because several changes in government occurred during legislative periods in Denmark and Norway, leading to new values for government par ticipation and government margin.

In addition, the different numbers of observations available per country pose some problems as cases within one country may not be completely independent. This seems less problematic with regard to this group of independent variables, though, as institutional variables are not included here.

55. The only available data not used are the Rice scores for Sweden in 1969. These values were extraordinarily low in some cases and showed up as significant outliers throughout the analyses.

56. Bille, 'Democratizing a Democratic Procedure: Myth or Reality?' Countries not covered there are coded using the data from K. Janda, Political Parties. A Cross national Survey 
(New York: Free Press, 1980). When procedures vary between parties in one system, I use the median category, which is also the modal category in all cases.

57. When using all observations in the data set instead of party averages, the difference is 1.54 points, significant at the 1 per cent level. This indicates that the lower levels of significance in the earlier tests (and maybe also in the tests to follow) are mainly due to the small number of cases.

58. Mitchell, 'Voters and Their Representatives'. I do not use Carey and Shugart's more elaborate scheme because I do not agree with their treatment of the single member simple plurality system as not providing incentives for pursuing a personal vote; Carey and Shugart, 'Incen tives to Cultivate a Personal Vote'.

59. The index value is calculated as the sum of the three individual variables coded as 1 if the resource is available to the individual MP, 5 if it is shared with the PPG or otherwise limited and 0 if it is not available or can only be accessed via the PPG. The data were taken from Inter Parliamentary Union (IPU), Parliaments of the World (Aldershot: Gower, 2nd ed., 1986), Table 6.1. Data on personal initiates were taken from I. Mattson, 'Private Members' Initi tatives and Amendments', in H. Döring (ed.), Parliaments and Majority Rule in Western Europe (Frankfurt: Campus, 1995), pp.448 87 and from IPU, Parliaments of the World, Table 29.

60. Index values below and equal to 1.5 are coded as low resources. The averages for the groups are 98.41 and 96.20, respectively. Data for Iceland are missing.

61. The average values are 97.78 and 96.15 , respectively. Expert judgements are taken from L. De Winter, 'The Role of Parliament in Government Formation and Resignation', in H. Döring (ed.), Parliaments and Majority Rule in Western Europe (Frankfurt: Campus, 1995), pp.115 51.

62. Data on ministers recruited from parliament were taken from L. de Winter, 'Parliamentary and Party Pathways to the Cabinet', in J. Blondel and J. Thiébault (eds.), The Profession of Gov ernment Ministers in Western Europe (Houndmills: Macmillan, 1991), pp.44 69.

63. For the German case, such a detailed analysis found evidence for the expected effect; Saalfeld, Parteisoldaten und Rebellen, pp.274 76.

64. Data on recall authority were taken from Damgaard, 'How Parties Control Committee Members', p.319. Systems not covered there were coded by the author based on the standing orders of the respective parliaments.

65. I. Mattson and K. Strøm, 'Parliamentary Committees', in H. Döring (ed.), Parliaments and Majority Rule in Western Europe (Frankfurt: Campus, 1995), pp.249 307. The data were taken from H. Döring, 'Time as a Scarce Resource: Government Control of the Agenda', in H. Döring (ed.), Parliaments and Majority Rule in Western Europe (Frankfurt: Campus, 1995), pp.223 46, Table 7.4 and Mattson and Strøm, 'Parliamentary Committees', Table 8.4. Countries not covered there were coded by the author based on information in IPU, Parliaments of the World, Table 33.4 and the standing orders of the respective parliaments.

66. The average values are 96.10 and 98.22 , respectively.

67. Data on the first three variables are available from various sources. The party manifesto data were taken from I. Budge et al., Mapping Policy Preferences. Estimates for Parties, Electors, and Governments, 19451998 (Oxford: Oxford University Press, 2001).

68. These country dummies also capture systematic measurement errors between countries resulting from different operational decisions and selection bias due to the different proportions of recorded votes. Thus, introducing country dummies helps ameliorate some of the problems necessarily tied to secondary data analyses like this one. Canada was chosen as the baseline of the model because it represents the median category with regard to average party unity on the system level and thus does not display a strong country specific pattern.

69. Government participation only barely misses the 10 per cent threshold with $p=0.109$.

70. Government participation is excluded in the last step of the stepwise procedure, falling only slightly short of the threshold with $p=0.053$.

71. Note that this finding is not due to the bias discussed by Desposato, who showed that the Rice Index is prone to overestimating the unity of small parties. If this was true for the data used here, the coefficient of PPG size should be even bigger. See Desposato, 'Correcting for Small Group Inflation of Roll call Cohesion Scores'. 
72. A. Przeworski and H. Teune, The Logic of Comparative Social Inquiry (New York: Wiley Interscience, 1970).

73. See Saalfeld, Parteisoldaten und Rebellen, pp. 286 308. One recent example is the appoint ment of Horst Seehofer to serve as Minister of Agriculture in the Merkel cabinet. Seehofer had been one of the most outspoken critics of many of the Christian Democrats' policy positions prior to the 2005 elections and had even resigned from his position as PPG spokesman for social and health policy because of policy disagreements with Angela Merkel (then head of the Christian Democratic PPG in the Bundestag).

74. T. Brechtel and A. Kaiser, 'Party System and Coalition Formation in Post Reform New Zealand', Political Science, 51 (1999), pp.3 26.

75. L. Bille, 'A Power Centre in Danish Politics', in K. Heidar and R. Koole (eds.), Parliamentary Party Groups in European Democracies (London: Routledge, 2000), pp.130 44.

76. Skjaeveland, 'Party Cohesion in the Danish Parliament'.

77. A Rice score of 96 points means that 98 per cent of a PPG vote together and 2 per cent oppose this view. If 98 per cent of the government party (or in case of coalitions, government parties) are to make up a majority of 50 per cent of the seats in parliament, the government's overall margin has to be higher than 50 per cent $/ 0.98=51.02$.

78. The data were taken from the Parliamentary Democracy Data Archive at www.pol.umu.se/ ccpd; see W.C. Müller and K. Strøm (eds.), Coalition Governments in Western Europe (Oxford: Oxford University Press, 2003) and K. Strøm, W.C. Müller and T. Bergman (eds.), Delegation and Accountability in Parliamentary Democracies (Oxford: Oxford University Press, 2003). The countries included in the data set are Austria, Belgium, Denmark, Finland, France, Germany, Greece, Iceland, Ireland, Italy, Luxembourg, the Netherlands, Norway, Portugal, Spain, Sweden and the UK.

79. W.H. Riker, The Theory of Political Coalitions (New Haven, CT: Yale University Press, 1962).

80. See, for example, on the Czech Republic L. Linek and P. Rakušanová, 'The More Parties Vote and the Bigger Their Majority Is, the Less United They Are', in Z. Mansfeldová, D.M. Olson and P. Rakušanova (eds.), Central European Parliaments. First Decade of Democratic Experience and the Future Prospective (Prague: Institute of Sociology, Academy of Sciences of the Czech Republic, 2004), pp.102 19 as well as the comparative data on Poland in Carey, 'Political Institutions, Competing Principals, and Party Unity in Legislative Voting'. 